\title{
Analisis Geologi Teknik Longsor di Desa Kuatae, Kecamatan Kota Soe, Nusa Tenggara Timur
}

\section{Engineering Geology Analysis of Slope Failure in Kuatae Village, Kota Soe District, East Nusa Tenggara}

\author{
Heri Syaeful $^{1 *}$, Dhatu Kamajati ${ }^{1}$, Yoshi Rachael ${ }^{1}$, Ebenheser Damaledo ${ }^{2}$ \\ ${ }^{1}$ Pusat Teknologi Bahan Galian Nuklir - BATAN \\ J1. Lebak Bulus Raya No. 9, Pasar Jumat, Jakarta, 12440 \\ ${ }^{2}$ Badan Penelitian dan Pengembangan Daerah Kabupaten TTS \\ Jl. Gunung Mollo, Kota Soe, Nusa Tenggara Timur, Indonesia, 85511 \\ *E-mail: syaeful@batan.go.id
}

Naskah diterima: 30 Oktober 2020, direvisi: 6 April 2021, disetujui: 22 April 2021

DOI: 10.17146/eksplorium.2021.42.1.6081

\begin{abstract}
ABSTRAK
Bencana alam longsor di Desa Kuatae, Kecamatan Kota Soe sering terjadi pada musim hujan. Longsor telah menyebabkan rusaknya rumah dan infrastruktur lainnya. Penelitian longsor dilakukan dengan pemetaan geologi teknik, pengeboran geologi teknik, uji laboratorium, analisis kestabilan lereng, dan identifikasi opsi penanggulangan. Berdasarkan hasil pemetaan, longsor terjadi dalam dua model, yaitu blok batugamping terumbu yang mengalami longsor translasi di atas napal dan batulempung serta longsor rotasi pada napal yang dikontrol oleh lapisan dasar yang kontak dengan batulempung. Hasil uji penetrasi standar pada batulempung dan napal menunjukkan nilai konsistensi yang sangat tinggi. Hasil analisis kestabilan lereng menunjukkan lereng dalam keadaan stabil tapi ternyata longsor masih terjadi di beberapa tempat pada area napal dan batulempung. Hal tersebut mengindikasikan bahwa material batuan mengalami degradasi kuat geser pada beberapa kondisi. Penelitian lebih lanjut terkait degradasi material batuan, seperti sifat tahan lekang dan lempung mengembang sangat penting untuk menentukan opsi penanggulangan yang paling tepat dilakukan pada kasus longsor di Desa Kuatae.
\end{abstract}

Kata kunci: Kota Soe, longsor, translasi, rotasi, degradasi kuat geser

\begin{abstract}
Landslides in Kuatae Village, Kota Soe District often occur during the rainy season. The slope failures cause damage to houses and other infrastructures. The research of slope failure has been carried out by using engineering geological mapping, engineering geological drilling, laboratory test, slope stability analysis, and identification of countermeasure options. Based on the mapping results, slope failures occur in two models, the first one was coral limestone blocks translation failure over marl and claystone, and the second one was rotation failure on marl that controlled by the base layer which contact with claystone. The result of the standard penetration test on claystone and marl showed a very high consistency value. The slope stability analysis had shown the slope is in a stable state, but slope failure occurred in several places on the marl and claystone area. Those indicated that the material had encounter shear strength degradation under several circumstances. Further investigation on the degradation of the rock material, such as slake durability and swelling clay are very important to determine the most appropriate countermeasure option to be applied in the landslide case of Kuatae Village.
\end{abstract}

Keywords: Kota Soe, landslide, translation, rotation, shear strength degradation 


\section{PENDAHULUAN}

Bencana alam longsor di Desa Kuatae, Kecamatan Kota Soe sering terjadi pada musim hujan. Longsor telah menyebabkan rusaknya rumah dan infrastruktur, seperti jalan, selokan, dan lain-lain. Masyarakat menyadari adanya bahaya longsor tetapi karena terdapat sumber air yang cukup melimpah dari mata air di sekitar lokasi longsor mereka memilih untuk tetap tinggal. Desa Kuatae termasuk dalam Kecamatan Kota Soe, Kabupaten Timor Tengah Selatan (TTS), Provinsi Nusa Tenggara Timur (NTT). Secara umum, Kabupaten TTS adalah wilayah semikering dengan curah hujan di bawah normal. Musim kemarau dapat mencapai 8-9 bulan dan sering terjadi kekeringan hampir sepanjang tahun. Kondisi lingkungan tidak mampu mendukung keberlangsungan pertanian dan menjamin ketersediaan air bersih untuk masyarakat [1].

Secara teknis, longsor di Desa Kuatae diperkirakan terjadi dalam dua model keruntuhan. Model pertama adalah keruntuhan translasi yang terjadi ketika massa batugamping terumbu terbelah dan bergerak turun sebagai blok massa di atas bidang gelincir berbentuk planar sedangkan model kedua adalah keruntuhan rotasi pada batulempung gampingan (napal) dan batulempung dengan faktor pemicu utama air [2]. Air hujan sebagai pemicu longsor telah lama diwaspadai, terutama di Indonesia yang beriklim tropis dan memiliki lapisan tanah lapukan yang tebal. Beberapa penelitian telah menyimpulkan bahwa intensitas curah hujan yang dapat menyebabkan longsor di suatu daerah adalah sekitar 16-22 mm/jam selama 5 jam atau dalam jangka pendek apabila di atas 50 mm/jam [3], [4]. Berdasarkan mekanisme, curah hujan yang tinggi menyebabkan naiknya tekanan air pori sedangkan penyebab lain seperti naiknya tekanan geser pada bidang profil tanah akibat beban tanah yang berat sangat kecil. Hal tersebut dibuktikan dengan banyaknya kejadian longsor di Desa Kuatae terjadi pada waktu hujan beberapa waktu yang lalu [5].

Ruang lingkup penelitian ini adalah memetakan sebaran batuan dan kondisi geologi tekniknya, melakukan pengeboran dan uji insitu, melakukan uji laboratorium, dan menganalisis kestabilan lereng. Tujuan penelitian ini adalah menentukan penyebab utama terjadinya longsor dan mengidentifikasi opsi penanggulangannya.

\section{METODOLOGI}

Investigasi tanah, dikombinasikan dengan uji lapangan dan uji laboratorium, berperan penting dalam karakterisasi profil tanah dan batuan untuk desain/perhitungan dan mengurangi ketidakpastian. Walaupun demikian, investigasi tanah sering terbatas lingkupnya karena tingginya biaya [6]. Kondisi ini juga terjadi pada investigasi tanah di Kecamatan Kota Soe, terutama dalam hal spesifikasi peralatan yang diperlukan untuk investigasi lapangan (pengeboran) dan analisis laboratorium.

\section{Pemetaan Geologi Teknik}

Pemetaan geologi teknik bertujuan untuk menentukan unit-unit geologi teknik yang terdiri dari empat komponen utama lingkungan geologi, yaitu batuan, air tanah, relief, dan proses geodinamik. Unit pemetaan geologi teknik adalah satuan zonasi pada suatu lembar peta. Zona geologi teknik tersebut merupakan area individu dalam peta, yang diinterpretasikan mempunyai homogenitas dalam cakupan data geologi teknik. Pemetaan geologi teknik difokuskan pada area longsor sampai batas-batas zona yang stabil. 


\section{Pengeboran Geologi Teknik}

Pengeboran geologi teknik bertujuan untuk mendapatkan data bawah permukaan di lokasi penelitian. Selain untuk memperoleh batuan inti bor yang relatif lebih segar, pengeboran juga sekaligus bertujuan untuk uji penetrasi standar (Standard Penetration Test/SPT) dan pengambilan sampel uji laboratorium. Pengeboran dilakukan di dua titik dengan jenis litologi yang berbeda.

\section{Uji Laboratorium}

Uji laboratorium yang dilakukan adalah analisis sifat fisik, termasuk di antaranya uji sifat tahan lekang (slake durability test) untuk mengetahui ketahanan batuan lunak dalam siklus pembasahan dan pengeringan. Selain analisis sifat fisik, parameter sifat teknik untuk analisis kestabilan lereng diperoleh dari uji laboratorium, yaitu kohesi (C) dan sudut geser dalam $(\varphi)$.

\section{Analisis Kestabilan Lereng}

Analisis kestabilan lereng mencakup tiga tahap utama, yaitu i) evaluasi dan interpretasi parameter, ii) penentuan lereng dan stratifikasi, dan iii) pemilihan metode analisis kestabilan lereng. Evaluasi dan interpretasi parameter mencakup data topografi, geologi, sifat fisik dan teknik, kondisi air tanah, dan beban-beban luar. Stratifikasi penampang lereng mencakup pemilihan bagian lereng yang akan dianalisis, informasi stratifikasi bawah permukaan, kedalaman muka air tanah, rekahan permukaan, dan lain-lain. Analisis kestabilan lereng dilakukan dengan metode analisis kesetimbangan batas (limit equilibrium analysis). Metode analisis berdasarkan kondisi geologi teknik lokasi penelitian telah banyak dikembangkan, seperti metode Fellenius yang digunakan dalam kasus bidang runtuh berupa busur lingkaran dengan mengabaikan resultan gaya antaririsan, metode Bishop untuk bidang runtuh berbentuk lingkaran dengan mempertimbangkan kesetimbangan gaya dan momen untuk masing-masing potongan, metode Janbu untuk bidang runtuh nonlingkaran, dan lain-lain [7] [9].

\section{Identifikasi Opsi Penanggulangan}

Opsi-opsi penanggulangan diidentifikasi berdasarkan kondisi yang memicu terjadinya longsor. Beberapa konsep penanggulangan yang dapat diterapkan antara lain i) mengurangi gaya-gaya yang menimbulkan gerakan tanah, seperti pengendalian air permukaan dan mengubah geometri lereng; ii) menambah gaya-gaya yang menahan gerakan dengan cara pengendalian air rembesan, penambatan, dan penimbunan pada lereng (beban kontra); iii) tindakan lain selain mengurangi dan menambah beban kontra, seperti relokasi, mengganti material, dan lainlain [8].

\section{HASIL DAN PEMBAHASAN Pemetaan Geologi Teknik}

Lokasi longsor secara geologis merupakan perselingan batulempung dan napal, setempat terdapat batugamping terumbu. Berdasarkan pengamatan lapangan, terlihat bahwa telah terjadi longsor pada batugamping terumbu dan tanah. Batugamping terumbu terdapat secara setempat dan lepas antara satu dengan lainnya. Bidang perlapisan batulempung dengan batugamping terumbu dapat diamati dengan cukup jelas. Mata air yang digunakan penduduk di bagian bawah lereng untuk keperluan rumah tangga sehari-hari terdapat pada bidang kontak perlapisan kedua litologi tersebut. Bidang kontak yang dapat diamati berkedudukan $\mathrm{N} 40^{\circ} \mathrm{E} / 30^{\circ}$ atau sejajar dengan kemiringan lereng yang sangat potensial menjadi bidang landasan longsor planar. 
Sementara itu, material tanah yang merupakan hasil pelapukan batulempung dan batugamping sebagian telah mengalami longsor.

Berdasarkan hasil pemetaan terdapat empat satuan batuan yang terdapat di lokasi longsor. Satuan batuan tersebut, dari tua ke muda, yaitu Satuan Batulempung, Satuan Napal, Satuan Batugamping Klastik, dan Satuan Batugamping Terumbu.

Satuan Batulempung merupakan satuan tertua yang tersingkap setempat di timur laut lokasi penelitian (di sekitar lokasi pengeboran KTE-02). Batuan ini berwarna abu-abu gelap yang mencirikan lokasi pengendapan laut dalam. Kenampakan singkapan batulempung pada kondisi segar secara umum adalah serpih abu-abu gelap dengan kohesivitas tinggi sedangkan pada kondisi lapuk adalah serpih abu-abu dengan kuat geser mendekati sifat tanah lempung.

Satuan Napal tersingkap secara luas di lokasi penelitian. Lapisan ini diperkirakan tidak terlalu tebal, sekitar puluhan meter. Pada kondisi segar batuan ini berwarna abu-abu terang sedangkan pada kondisi lapuk berwarna abu-abu keputihan. Napal pada beberapa lokasi mengandung sedikit pasir halus dan setempat terdapat lapisan batugamping terumbu dan batugamping klastik dengan ketebalan 0,2-2 meter. Pada lokasi pengeboran pertama (KTE-01) kontak satuan batulempung dan napal terlihat pada kedalaman 15,5 meter.

Satuan Batugamping Klastik tersingkap di bagian tengah lokasi penelitian. Batuan ini berwarna abu-abu kekuningan, tersusun oleh fragmen batugamping dan matriks gamping pasiran. Ketebalan satuan ini sekitar 10 meter.

Satuan Batugamping Terumbu terletak di utara lokasi penelitian yang merupakan daerah tinggian pada sistem lereng di Desa Kuatae. Batuan ini berwarna abu-abu gelap, keras, berongga, dengan ketebalan teramati mencapai lebih dari 30 meter. Gejala pelarutan yang menyebabkan batuan patah dan terpisah dari tubuh utamanya dapat diamati di beberapa tempat.

Satuan Batugamping Terumbu terdapat menumpang di atas batuan napal. Secara umum, satuan ini merupakan tinggian di wilayah Kecamatan Kota Soe. Tebal satuan ini diperkirakan mencapai puluhan meter. Satuan ini pada sistem lereng rawan longsor di Desa Kuatae membentuk gawir yang cukup panjang berarah $\mathrm{N} 60^{\circ} \mathrm{E}$. Di bagian atas gawir terdapat beberapa bukaan pelarutan yang cukup lebar dan memanjang (Gambar 1). Beberapa blok massa batuan batugamping terumbu terlihat terlepas dan mengalami longsor translasi di atas permukaan batulempung (Gambar 2).

Selain dinding gawir yang terjal, ronggarongga yang cukup dalam terdapat pada lereng tersebut. Rongga pada batugamping terumbu dapat terbentuk dalam dua model, yaitu gua bawah tanah yang luas pada area kars serta fraktur pada batugamping dan dolomit [10]. Berdasarkan keterangan yang didapat, pada lokasi tersebut terdapat gua yang di dalamnya ditemukan air. Penyebab keberadaan gua didukung dengan petunjuk berupa beberapa fenomena penurunan tanah di sekitar lokasi. Kondisi seperti ini menunjukkan bahwa terdapat bahaya lain yang harus diinvestigasi selain bahaya longsor itu sendiri.

Area yang mengalami longsor pada tahun 2011 dijumpai pada Satuan Napal. Longsor ini memiliki dimensi yang cukup besar, yaitu lebar \pm 30 meter, panjang lebih dari 50 meter, dan kedalaman \pm 10 meter dengan material longsor berupa batugamping dan batulempung. Pada area tersebut dijumpai aliran air dengan debit sekitar 0,5 liter/detik. Mahkota longsor dan bidang gelincir terlihat relatif berbentuk sirkuler. 
Hal yang menjadi catatan penting adalah kejenuhan air yang terus meningkat karena adanya aliran air di permukaan dapat mengubah sifat teknik batuan. Sifat teknik material napal dapat berubah secara drastis menjadi tidak kohesif dan mengalami longsor seperti tanah. Menurut informasi penduduk, lokasi longsor pada Satuan Napal tersebut awalnya memiliki lereng yang tidak terlalu terjal hingga pada tahun 2011, yang merupakan tahun dengan curah hujan yang tinggi, terjadi gejala mirip amblesan tanah dengan penurunan lebih dari $15 \mathrm{~m}$ (Gambar 3). Detail peta geologi disertai lokasi titik bor, lokasi mata air, dan sebaran geologi ditampilkan pada Gambar 4.

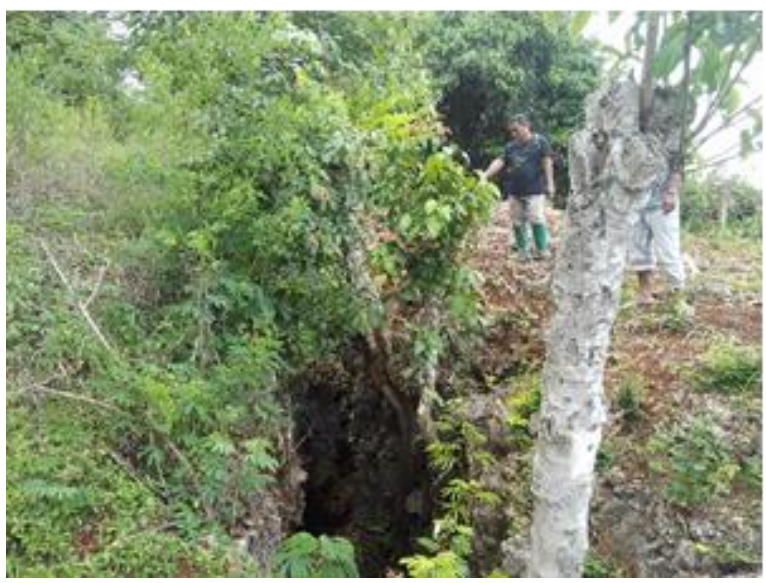

Gambar 1. Bukaan hasil pelarutan pada batugamping terumbu.

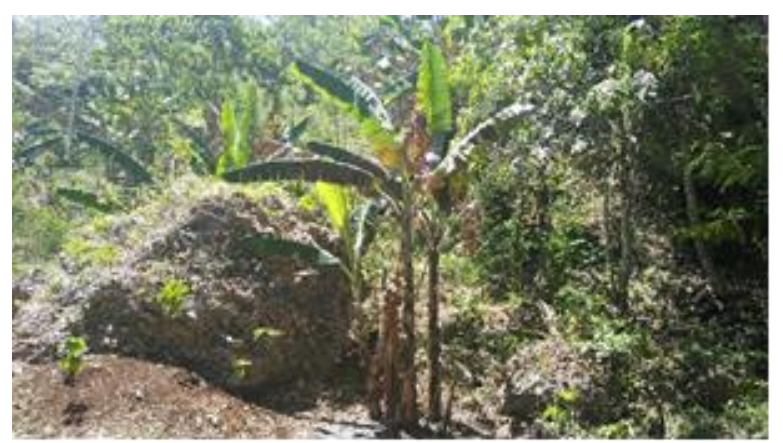

Gambar 2. Blok massa batugamping terumbu yang mengalami longsor translasi di atas bidang permukaan batulempung.

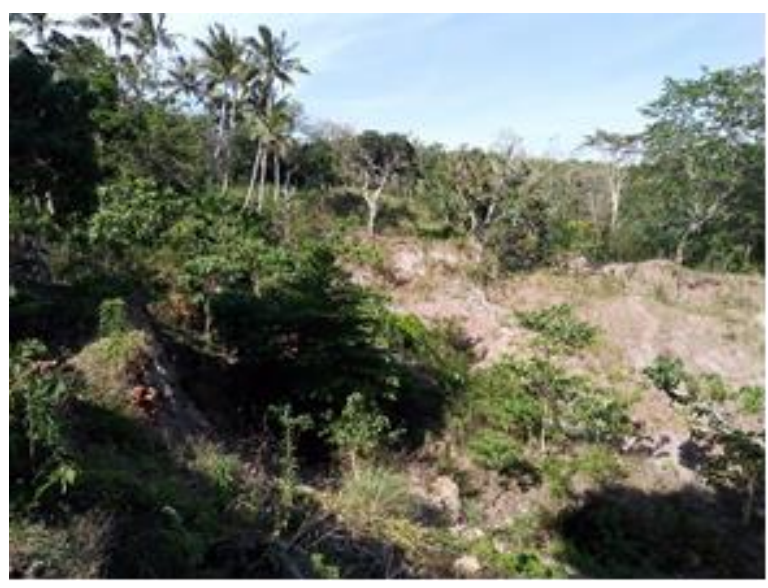

Gambar 3. Daerah longsor di sebaran Satuan Napal.

\section{Pengeboran Geologi Teknik}

Pengeboran geologi teknik dilakukan pada dua titik dengan kedalaman masingmasing 30 meter. Pengeboran dilakukan menggunakan bor putar dengan metode pengintian bor (coring). Selain untuk pengamatan geologi bawah permukaan, pengintian bor juga bertujuan untuk mendapatkan sampel tanah atau batuan untuk uji laboratorium. Setiap inti bor yang terambil dimasukkan ke kotak inti dan dicatat kedalamannya. Inti bor dibungkus dengan plastik sebelum dimasukkan ke kotak inti untuk menjaga kandungan air.

Pada kegiatan pengeboran geologi teknik ini uji SPT dilakukan dengan interval 5 meter. Tujuan uji SPT adalah untuk mengetahui tingkat kepadatan napal atau kekerasan batulempung dan sebagai pembanding parameter kuat geser yang diperoleh dari uji laboratorium. Nilai pembacaan uji SPT pada batuan di bor KTE-01 sekitar 35 (hard consistency) pada kedalaman hingga 5 meter dan 48-94 (very hard consistency) pada kedalaman 5 sampai 30 meter. Pada bor KTE02 SPT napal berkisar antara 35 dan 83 (hard consistency-very hard consistency) dan batulempung di bawahnya berkisar antara 84 dan 92 (very hard consistency) (Gambar 5) [11]. 


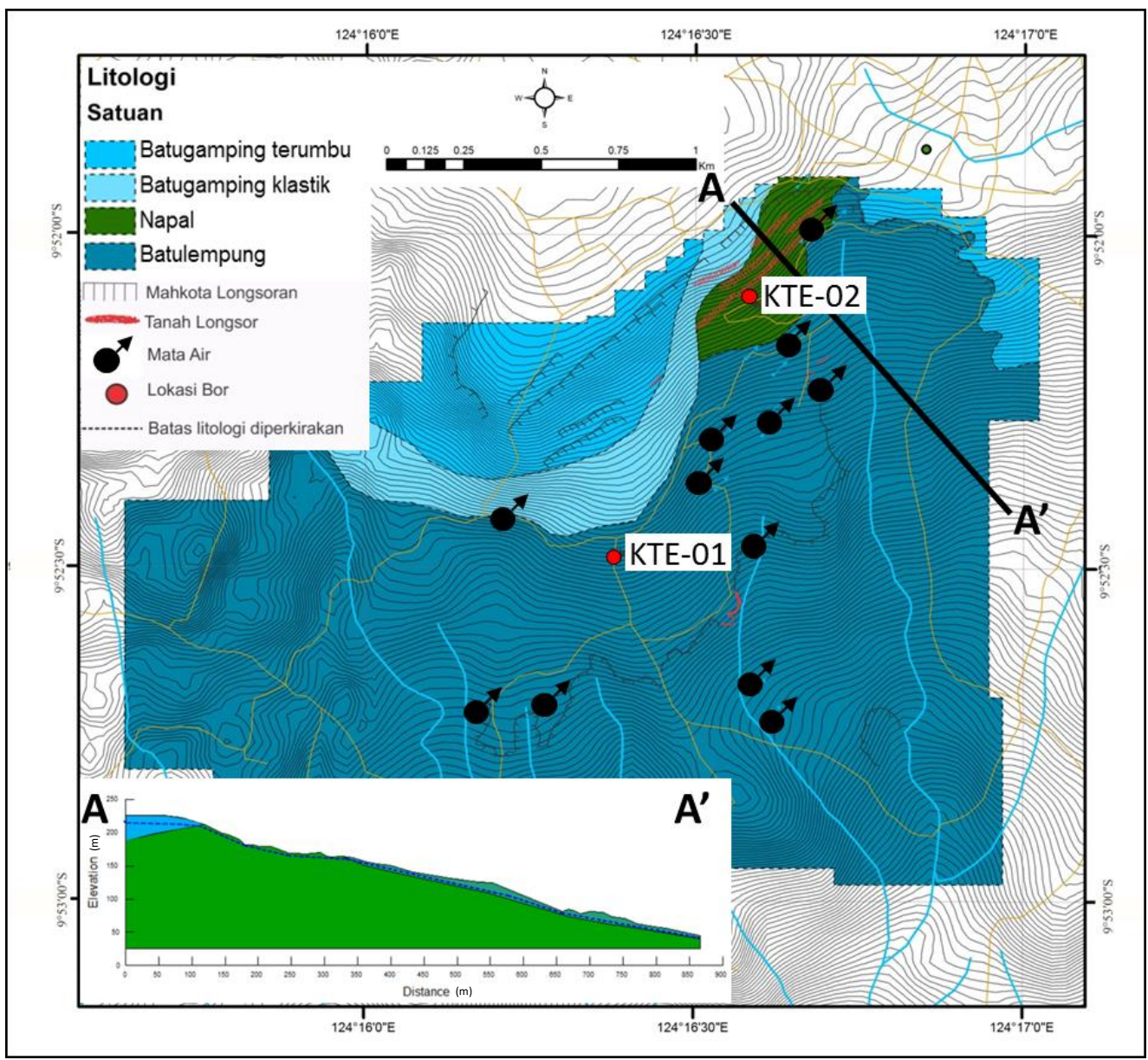

Gambar 4. Peta geologi teknik lokasi longsor.

Setelah kegiatan pengeboran geologi teknik selesai, dilakukan pemasangan pipa piezometer. Pemasangan ini dilakukan untuk memantau muka air tanah. Kedalaman muka air tanah pada lokasi bor KTE-01 adalah 2,7 meter dan pada lokasi bor KTE-02 adalah 7,6 meter. Data muka air tanah selanjutnya akan digunakan dalam analisis kestabilan lereng.
Profil tanah/batuan di lubang bor KTE01, dari tua ke muda, tersusun atas batulempung (14 meter), napal (14 meter), batugamping klastik (1,5 meter) dan tanah lapukan ( 0,5 meter). Sementara itu, pada KTE02 , profil tersusun atas batulempung (27 meter) dan tanah lapukan (3 meter) (Gambar 5).

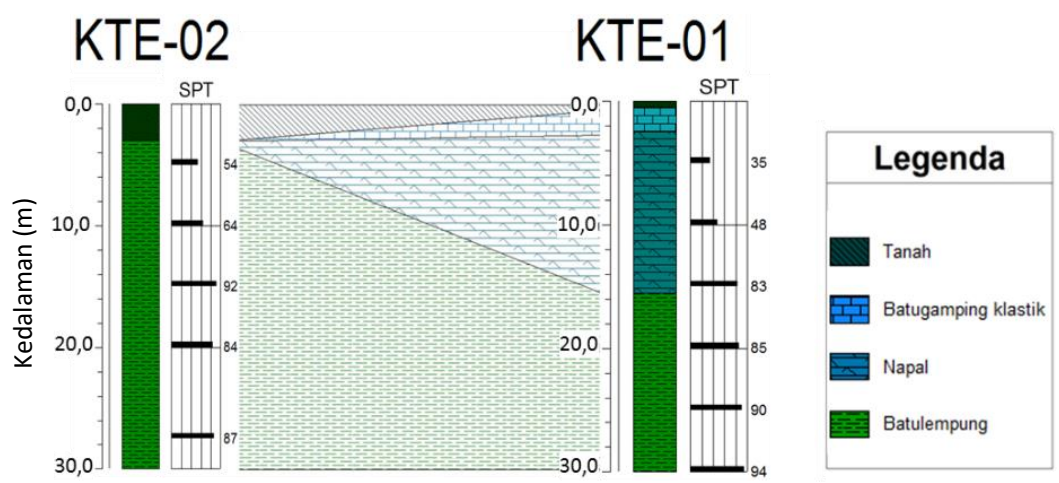

Gambar 5. Profil bor dan korelasi litologi. 


\section{Uji Laboratorium}

Terdapat dua jenis sampel yang digunakan dalam uji laboratorium, yaitu sampel inti bor yang diperoleh dari pengeboran dan sampel tanah terganggu (disturbed) yang diperoleh dari pengambilan sampel batuan di permukaan. Pengambilan contoh menggunakan metode sampel tanah tidak terganggu (undisturbed sample/UDS) tidak dapat dilakukan karena konsistensi batuan yang sangat tinggi [12]. Material lempung secara umum diketahui memang sulit untuk diperoleh dengan metode UDS sehingga sebagai alternatif diambil sampel tanah terganggu dari bor dan batuan di permukaan. Sampel batuan permukaan selanjutnya dicetak ulang terlebih dahulu sebelum dianalisis sifat tekniknya [13].

Penelitian mengenai sifat teknik/mekanik sampel cetak ulang telah banyak dilakukan. Secara umum sifat teknik sampel tanah yang dicetak ulang lebih baik karena tidak ada celah (fissure) dalam tanah dan tersusun kembalinya partikel tanah dan pori-pori [14]. Selain itu, jika dibandingkan dengan sampel tidak terganggu, sampel yang dicetak ulang cenderung lebih baik sifat tekniknya karena memiliki kandungan air yang lebih rendah [15].

Analisis dilakukan di dua laboratorium mekanika tanah untuk mendapatkan perbandingan hasil analisis, yaitu di Laboratorium Pengujian dan Bina Teknik, Dinas Pekerjaan Umum Provinsi NTT (Tabel 1) dan di Laboratorium Mekanika Tanah, Pusat Penelitian dan Pengembangan Teknologi Mineral dan Batubara (tekMIRA), Bandung (Tabel 2). Kode KTE menunjukkan sampel yang berasal dari pengeboran sedangkan RSD merupakan sampel residu tanah/batuan permukaan. Parameter yang diuji adalah sifat indeks yang meliputi ukuran butir, kadar air, berat jenis, berat alami, berat kering, batas-batas Atterberg, batas penyusutan, hidrometri, dan tahan lekang. Sifat teknik diperoleh dari uji geser langsung (direct shear).

Catatan penting yang diperoleh dari analisis sifat fisik tahan lekang yang bertujuan untuk menganalisis potensi degradasi suatu batuan adalah nilai tahan lekang satuan batulempung sekitar $5,5 \%$ termasuk dalam kategori durabilitas sangat rendah atau bahkan diklasifikasikan sebagai material non-durable [11]. Penelitian lain mengenai degradasi sifat teknik batulempung akibat terekspos oleh air dan cuaca menunjukkan bahwa kohesi batuan dapat turun lebih dari 50\% dalam waktu sekitar 1 tahun [16]. Berdasarkan data indeks plastisitas, terutama dari sampel inti bor yang dianalisis di tekMIRA diperoleh nilai 33,27 (tinggi-sangat tinggi) dan 79,89 (sangat tinggi). Sementara itu, berdasarkan data batas cair diperoleh nilai 112,00 (sangat tinggi) dan 59,30 (tinggi) [17], [18].

\section{Analisis Kestabilan Lereng}

Analisis kestabilan lereng dilakukan berdasarkan model keruntuhan lereng yang terjadi di lapangan. Terdapat dua model keruntuhan lereng yang dapat diterapkan di lokasi ini. Model pertama adalah keruntuhan translasi yang terjadi ketika massa batugamping yang terpecah bergerak sebagai blok di atas bidang gelincir planar permukaan napal (batulempung gampingan) atau batulempung. Model kedua adalah keruntuhan rotasi yang ditandai dengan bidang gelincir berbentuk sirkuler. Gawir melengkung terbentuk di lereng bagian atas dan bagian labil dengan kenampakan bergelombang terdapat di bagian tengah longsor. Keruntuhan lereng ini terjadi di lokasi penelitian pada Satuan Napal, memiliki gerakan progresif, serta meliputi daerah yang cukup luas. Rotasi pada tanah ditandai dengan adanya bidang gelincir 
lengkung dan gerakan rotasi. Penyebab utama terjadinya keruntuhan rotasi adalah gaya-gaya yang timbul dari rembesan air tanah atau kemiringan lereng yang bertambah pada tanah residual.

Berdasarkan referensi tentang pola keruntuhan lereng yang disesuaikan dengan bukti lapangan, analisis kestabilan lereng dapat dilakukan dengan metode analisis kesetimbangan batas (limit equilibrium analysis). Berdasarkan kondisi geologi teknik lokasi penelitian, pendekatan metode yang dipilih adalah metode Janbu yang dapat diterapkan pada bidang runtuhan nonlingkaran yang dipengaruhi oleh bidang alas berupa kontak napal dan batulempung.

Tabel 1. Hasil analisis sifat fisik dan sifat teknik di Laboratorium Pengujian dan Bina Teknik, Dinas Pekerjaan Umum Provinsi NTT.

\begin{tabular}{|c|c|c|c|c|c|c|c|c|c|}
\hline \multirow[t]{2}{*}{$\begin{array}{c}\text { No. } \\
\text { Sampel }\end{array}$} & \multirow{2}{*}{$\begin{array}{c}\text { Kedalaman } \\
\text { (m) }\end{array}$} & \multirow{2}{*}{$\begin{array}{c}\text { Kadar } \\
\text { Air } \\
\text { Wn } \\
(\%)\end{array}$} & \multirow{2}{*}{$\begin{array}{c}\text { Berat } \\
\text { Isi } \\
\gamma \mathbf{n} \\
\left(\mathbf{k N} / \mathbf{m}^{3}\right)\end{array}$} & \multirow{2}{*}{$\begin{array}{c}\text { Berat Isi } \\
\text { Kering } \\
\gamma d \\
\left(\mathrm{gr} / \mathrm{cm}^{3}\right)\end{array}$} & \multicolumn{3}{|c|}{ Batas-Batas Atterberg } & \multicolumn{2}{|c|}{$\begin{array}{l}\text { Uji Geser } \\
\text { Langsung }\end{array}$} \\
\hline & & & & & $\begin{array}{l}W_{L} \\
(\%)\end{array}$ & $\begin{array}{c}W_{P} \\
(\%)\end{array}$ & $\begin{array}{c}\mathbf{I}_{\mathbf{P}} \\
(\%)\end{array}$ & $\begin{array}{c}\varphi \\
(\operatorname{deg})\end{array}$ & $\begin{array}{c}\mathrm{C} \\
\left(\mathrm{kN} / \mathrm{m}^{2}\right)\end{array}$ \\
\hline KTE-01 & $4,5-5,0$ & 37,26 & 16,87 & 12,29 & 47,08 & 24,72 & 22,40 & 50,88 & 20,84 \\
\hline KTE-01 & $14,5-15,0$ & - & - & - & 59,70 & 30,62 & 29,09 & 49,38 & 24,46 \\
\hline KTE-02 & $5,0-5,5$ & 38,42 & 16,98 & 12,27 & 47,21 & 21,16 & 26,05 & 50,33 & 22,19 \\
\hline KTE-02 & $13,5-14$ & - & - & - & 56,97 & 24,04 & 32,93 & 49,07 & 25,03 \\
\hline RSD-1 & - & - & - & - & - & - & - & 46,67 & 25,92 \\
\hline RSD-2 & - & - & - & - & - & - & - & 49,10 & 22,94 \\
\hline RSD-3 & - & 38,33 & 16,83 & 12,17 & - & - & - & 48,55 & 24,69 \\
\hline RSD-4 & - & 36,78 & 16,85 & 12,32 & - & - & - & 47,77 & 24,56 \\
\hline RSD-5 & - & 34,31 & 16,90 & 12,58 & - & - & - & 46,11 & 27,75 \\
\hline
\end{tabular}

Tabel 2. Hasil analisis sifat fisik dan sifat teknik di Laboratorium Mekanika Tanah, Pusat Penelitian dan Pengembangan Teknologi Mineral dan Batubara (tekMIRA), Bandung.

\begin{tabular}{|c|c|c|c|c|c|}
\hline \multirow{2}{*}{\multicolumn{3}{|c|}{$\begin{array}{l}\text { Sample Code } \\
\text { Depth (m) } \\
\text { Physical Characteristics }\end{array}$}} & $\begin{array}{c}\text { KTE-01 } \\
\text { 10,55-11,00 }\end{array}$ & $\begin{array}{c}\text { KTE-02 } \\
6,45-6,60\end{array}$ & $\begin{array}{c}\text { KTE-03 } \\
\text { 10,55-11,00 }\end{array}$ \\
\hline & & & & & \\
\hline \multicolumn{2}{|c|}{ Natural Water Content } & $\%$ & 24,63 & 25,33 & - \\
\hline \multicolumn{2}{|c|}{ Spesific Gravity } & - & 2,08 & 2,60 & - \\
\hline \multicolumn{2}{|c|}{ Unit Weight Natural State } & $\mathrm{gr} / \mathrm{cm}^{3}$ & 2,00 & 1,95 & - \\
\hline \multicolumn{2}{|c|}{ Dry Unit Weight } & $\mathrm{gr} / \mathrm{cm}^{3}$ & 1,61 & 1,56 & - \\
\hline \multicolumn{2}{|l|}{ Saturation } & $\%$ & 96,51 & 95,13 & - \\
\hline \multicolumn{2}{|l|}{ Natural Porosity } & \multicolumn{3}{|c|}{ Natural Void } & - \\
\hline \multicolumn{2}{|l|}{ Ratio } & - & 0,67 & 0,67 & - \\
\hline \multirow[t]{3}{*}{ Atterberg Limits } & Liquid Limit & $\%$ & 112,00 & 59,30 & - \\
\hline & $\begin{array}{l}\text { Plastic Limit } \\
\text { Plasticity }\end{array}$ & $\%$ & 32,11 & 26,03 & - \\
\hline & Index & $\%$ & 79,89 & 33,27 & - \\
\hline \multicolumn{2}{|l|}{ Shrinkage Limit } & $\%$ & 26,10 & 27,66 & - \\
\hline \multirow[t]{4}{*}{ Hydrometry } & Gravel & $\%$ & 0,00 & 0,00 & - \\
\hline & Sand & $\%$ & 1,10 & 7,00 & - \\
\hline & Silt & $\%$ & 16,60 & 44,30 & - \\
\hline & Clay & $\%$ & 82,30 & 48,70 & - \\
\hline \multicolumn{2}{|l|}{ Slake Durability } & $\%$ & - & - & 5,50 \\
\hline \multicolumn{6}{|c|}{ Mechanics Characteristic } \\
\hline Direct Shear Test & $\begin{array}{l}\text { Cohesion } \\
\text { Int. Fric. } \\
\text { Angle }\end{array}$ & $\mathrm{kPa}$ & 46,04 & - & - \\
\hline
\end{tabular}


Pada tahap awal dibuat stratifikasi penampang lereng. Stratifikasi penampang lereng adalah suatu penampang yang menunjukkan urutan lapisan tanah/batuan dari muka tanah sampai batas kedalaman penyelidikan. Penampang ini dihasilkan dari korelasi lapisan berdasarkan jenis, sifat fisik, dan sifat teknik lapisan tanah/batuan. Pembuatan penampang lereng dilakukan dengan mengukur jarak dan sudut kemiringan lereng pada setiap perubahan geometri lereng dengan menggunakan meteran, kompas, dan klinometer. Profil lereng yang dipilih untuk analisis kestabilan adalah bagian tengah yang relatif mewakili kondisi kestabilan lereng di Desa Kuatae.

Parameter sifat fisik dan sifat teknik yang digunakan dalam analisis kestabilan diambil dari data hasil uji laboratorium yang dikomparasi dengan referensi sifat kuat geser batuan kohesif berdasarkan nilai SPT. Parameter kuat geser batugamping terumbu menggunakan sifat impenetrable (tidak dapat ditembus bidang keruntuhan) karena memiliki pola keruntuhan yang berbeda dengan konsep analisis kesetimbangan batas. Material batugamping sendiri secara fisik dan teknik memiliki berat isi, porositas, kecepatan sonik, dan kekuatan medium. Batuan ini memiliki sifat tahan lekang yang sangat tinggi [19].

Napal, mengacu pada hasil uji laboratorium Dinas Pekerjaan Umum Provinsi NTT terhadap sampel cetak ulang, tidak memperlihatkan sifat batuan kohesif, memiliki sudut geser dalam yang sangat tinggi, yaitu antara $46,11^{\circ}$ dan $50,88^{\circ}$, bahkan melebihi sifat tanah nonkohesif dengan sudut geser dalam di atas $45^{\circ}$ [11]. Berdasarkan hasil uji laboratorium tekMIRA, nilai sudut geser dalam yang sebesar $12,95^{\circ}$ sesuai dengan sifat material kohesif tetapi nilai kohesi $46,04 \mathrm{kPa}$ masih terlalu rendah bila dibandingkan dengan batulempung atau napal yang memiliki konsistensi tinggi. Bacaan nilai SPT yang selalu di atas 30 menunjukkan kategori konsistensi keras sampai sangat keras [11]. Kondisi menurunnya kohesi diperkirakan karena sampel yang diambil merupakan sampel terganggu dari inti bor yang telah terkena proses rotasi selama pengeboran. Proses rotasi selama pengeboran tersebut diduga membuat struktur batuan melemah dan sifat kohesi terdegradasi. Berdasarkan uraian tersebut maka nilai kohesi diambil secara teoretis berdasarkan bacaan nilai SPT. Berdasarkan kekerasan batuan pada kondisi segar, batulempung bersifat seperti batuan dasar yang mengontrol longsor tipe translasi sehingga dikategorikan sebagai impenetrable (Tabel 3).

Tabel 3. Data masukan sifat fisik dan teknik untuk analisis kestabilan lereng

\begin{tabular}{lccc}
\hline \multicolumn{1}{c}{ Litologi } & $\begin{array}{c}\text { Berat Isi } \\
\left(\mathbf{k N} / \mathbf{m}^{\mathbf{3}}\right)\end{array}$ & $\begin{array}{c}\boldsymbol{\varphi} \\
(\mathbf{d e g})\end{array}$ & $\begin{array}{c}\mathbf{C} \\
\left(\mathbf{k N} / \mathbf{m}^{\mathbf{2}}\right)\end{array}$ \\
\hline Napal & 20,00 & 50,88 & 20,84 \\
Batulempung & \multicolumn{3}{c}{ Impenetrable } \\
\hline
\end{tabular}

Analisis kestabilan lereng dilakukan dengan metode Janbu. Posisi bidang gelincir minimum ditentukan dengan grid dan radius. Berdasarkan hasil analisis diperoleh bahwa nilai faktor keamanan (FK) lereng pada kondisi normal berada pada kategori sangat stabil, yaitu FK 3,33 (Gambar 6). Analisis kestabilan lereng pada kondisi dinamik dengan menerapkan beban gempa periode ulang 500 tahun dengan percepatan sebesar 0,25 g menghasilkan nilai FK 1,96 (kategori stabil) [20] (Gambar 7). 


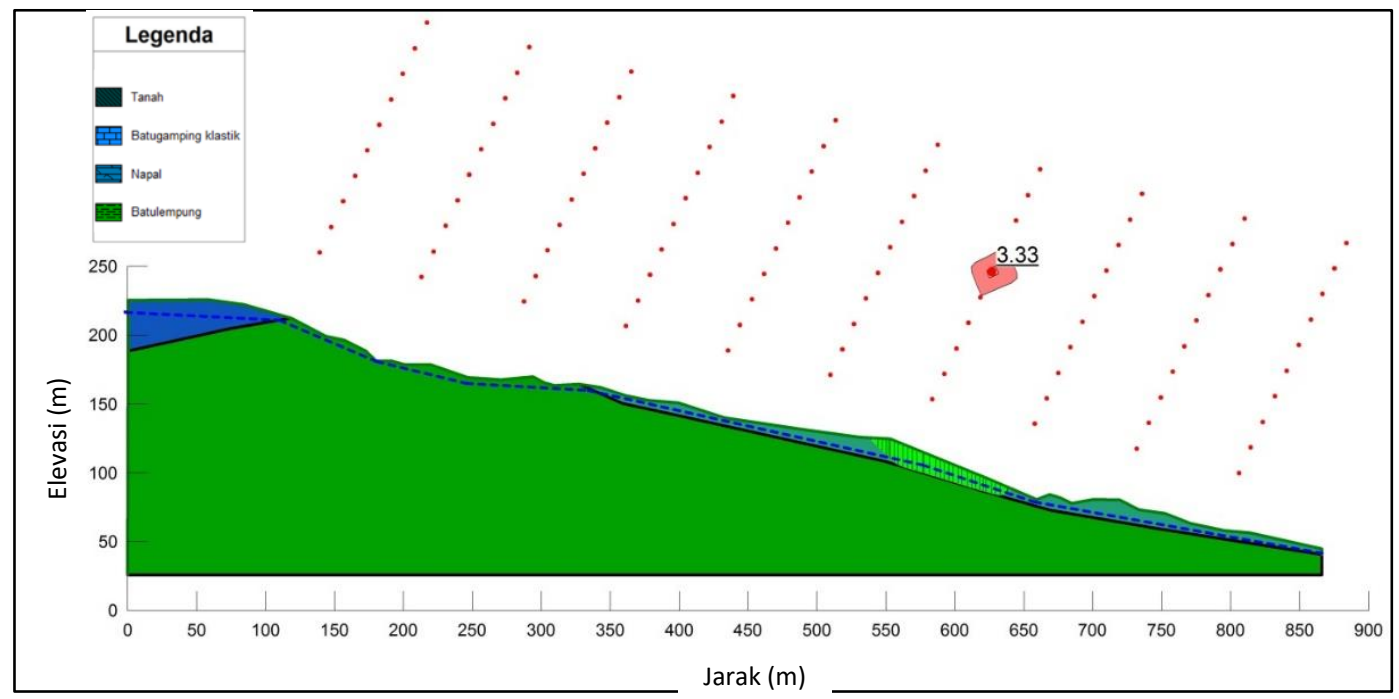

Gambar 6. Analisis kestabilan lereng dalam kondisi normal.

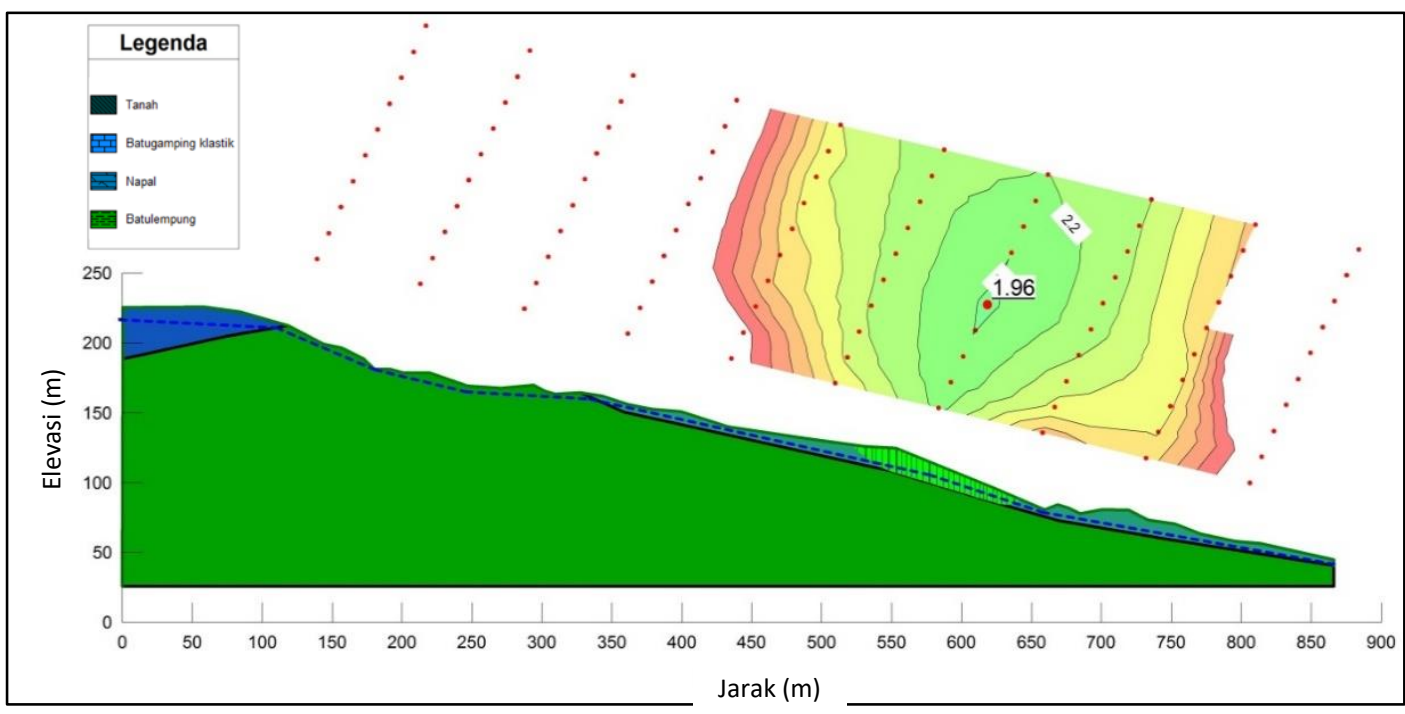

Gambar 7. Analisis kestabilan lereng dalam kondisi dinamik.

Terjadinya longsor pada napal mengindikasikan adanya penurunan kohesivitas yang kemungkinan disebabkan oleh sangat rendahnya sifat tahan lekang. Berdasarkan simulasi penurunan FK pada lereng maka diperkirakan kohesi napal dapat turun $80 \%$ dari $192 \mathrm{kPa}$ menjadi $30 \mathrm{kPa}$ akibat pengaruh air dan cuaca (Gambar 8). Kondisi diperparah dengan adanya aliran air pada bidang kontak lapisan ketika curah hujan tinggi.

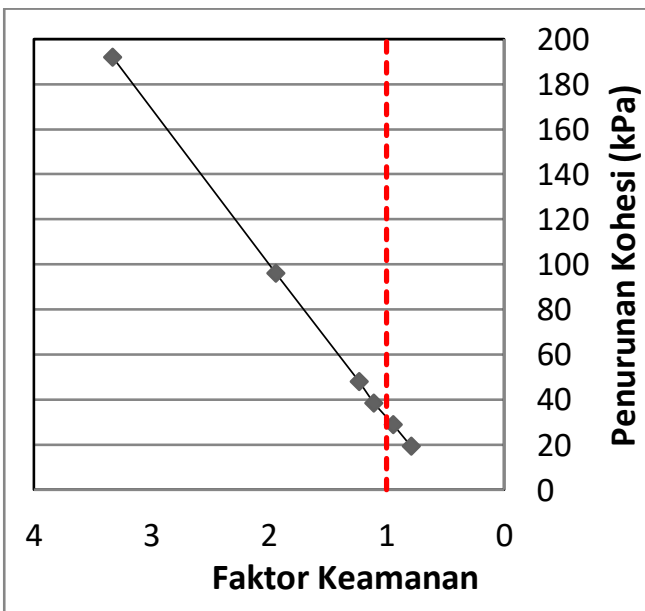

Gambar 8. Simulasi variasi Faktor Keamanan akibat penurunan kohesi. 


\section{Identifikasi Opsi Penanggulangan}

Berdasarkan pengamatan lapangan, air merupakan penyebab utama terjadinya longsor di Desa Kuatae. Pada musim hujan dengan durasi hujan yang lama dan debit mata air tinggi, lereng rawan longsor karena batulempung sebagai batuan dasar tidak dapat menyerap air sehingga sebagian besar air mengalir di permukaan tanah. Pada batugamping terumbu, air melarutkan dan membuat celah-celah pada tubuh batuan sehingga batugamping patah dan terpisah sebagai blok-blok massa. Fragmen batugamping tersebut berada di atas batulempung yang relatif miring sejajar dengan lereng sehingga fragmen batugamping dapat longsor setiap saat, tergantung pada kohesi batulempung atau batulempung gampingan. Jika terdapat aliran air tinggi pada kontak kedua batuan tersebut maka kohesi akan hilang dan batugamping terumbu akan mengalami longsor translasi mengikuti permukaan batulempung seperti yang telah terjadi di Desa Kuatae.

Pada kondisi lain, air dapat meningkatkan kejenuhan batulempung dan batulempung gampingan sehingga berat isi material meningkat. Selain itu, kohesi pada tanah residual hasil pelapukan batulempung dan batulempung gampingan dapat berkurang akibat pengaruh air dan cuaca. Untuk meminimalisasi pengaruh air dapat dilakukan pengendalian air permukaan dan pengendalian air rembesan. Pengendalian air permukaan dapat dilakukan dengan perbaikan saluran permukaan. Saluran permukaan pada beberapa tempat masih terbuka sehingga beban lereng bertambah. Pengamatan pada beberapa lokasi menunjukkan drainase permukaan berupa selokan belum tertata dengan baik. Pengendalian air rembesan dapat dilakukan dengan sistem intercept drains, yaitu saluran penampung air sebelum mengalir ke sistem lereng.

Pada kasus longsor batugamping terumbu, mitigasi merupakan opsi penanggulangan terbaik karena pada sistem lereng Desa Kuatae kondisi longsor sulit dicegah. Mitigasi dapat dilakukan dengan pembuatan sistem bench dan parit yang berfungsi sebagai penangkap batuan sehingga batuan yang longsor tidak membahayakan masyarakat dan infrastruktur di bagian bawah lokasi longsor [21]. Selain pembuatan sistem penangkap batuan, sistem proteksi lereng juga dapat diaplikasikan, yaitu dengan memasang wire meshes yang diperkuat dengan rockbolts [22].

\section{KESIMPULAN}

Air permukaan menyebabkan blok batugamping terumbu yang telah terlepas dari massa batuan utamanya menggelincir. Air juga menyebabkan terjadinya longsor pada Satuan Napal. Air dan longsor juga dikontrol oleh bidang kontak napal dan batulempung di bawahnya. Ketebalan lapisan napal diperkirakan mencapai belasan meter. Hasil uji SPT memperlihatkan kondisi napal dan batulempung memiliki konsistensi sangat tinggi, tapi tetap mengalami longsor sehingga diperkirakan terjadi degradasi kuat geser batuan yang dipengaruhi oleh sifat material. Opsi penanggulangan terbaik saat ini adalah mitigasi dengan cara perbaikan drainase permukaan dan drainase rembesan serta pembuatan parit atau bench penangkap material batugamping terumbu yang longsor. Sistem penangkap material longsor dapat dilengkapi dengan sistem proteksi lereng berupa wire meshes dan rockbolts. Penelitian lebih lanjut tentang degradasi material, seperti sifat tahan lekang dan lempung mengembang sangat penting dilakukan untuk menentukan opsi penanggulangan yang paling tepat pada kasus longsor di Desa Kuatae. 


\section{UCAPAN TERIMA KASIH}

Penulis mengucapkan terima kasih kepada Pemerintah Kabupaten Timor Tengah Selatan, khususnya eks Dinas Energi dan Sumber Daya Mineral yang telah bekerja sama dengan kami dalam penelitian ini. Selain itu, penulis juga berterima kasih kepada Bapak Suharji dan Bapak Setya Darmono yang telah membantu pelaksanaan penelitian, serta Bapak Agus Sumaryanto yang telah memfasilitasi keseluruhan penelitian secara teknis dan administratif.

\section{DAFTAR PUSTAKA}

[1] H. Jocom, D. D Kameo, I. Utami, dan A. I. Kristijanto, "Air dan Konflik: Studi Kasus Kabupaten Timor Tengah Selatan," J. Ilmu Lingkung., vol. 14, no. 1, hal. 51-61, 2016, doi: 10.14710/jil.14.1.51-61.

[2] Pemerintah Kabupaten Timor Tengah Selatan, Kajian Lingkungan Hidup Strategis. Soe, 2017.

[3] R. Hidayat, S. Jonson Sutanto, dan M. Deddy Munir, "Kondisi Geologi Dan Pola Hujan Sebagai Pemicu Longsor Di Jawa Tengah Bagian Selatan Pada Juni 2016," Tek. Hidraul., vol. 7, no. 2, hal. 147-162, 2016.

[4] Hasnawir, "Intensitas Curah Hujan Memicu Tanah Longsor Dangkal di Sulawesi Selatan," J. Penelit. Kehutan. Wallacea, vol. 1, no. 1, hal. 62-73, 2012, doi: 10.18330/jwallacea.2012.vol1iss1pp62-73.

[5] Y. Chen, K. R. Withanage, T. Uchimura, W. Mao, dan W. Nie, "Shear Deformation and Failure of Unsaturated Sandy Soils in Surface Layers of Slopes During Rainwater Infiltration," Meas. J. Int. Meas. Confed., vol. 149, 2020, doi: 10.1016/j.measurement.2019.107001.

[6] R. Yang, J. Huang, D. V. Griffiths, J. Meng, dan G. A. Fenton, "Optimal Geotechnical Site Investigations for Slope Design," Comput. Geotech., vol. 114, no. May, 2019, doi: 10.1016/j.compgeo.2019.103111.

[7] R. Indera K., E. Mina, dan S. B, "Analisis Stabilitas Lereng dan Perencanaan Soil Nailing dengan Software Geostudio 2007," Fondasi, vol. 4, no. 1, 2015.

[8] Departemen Pekerjaan Umum, Rekayasa Penanganan Keruntuhan Lereng pada Tanah Residual dan Batuan, no. Pd T-09-2005-B. 2005.

[9] A. Su, Z. Zou, Z. Lu, dan J. Wang, "The Inclination of the Interslice Resultant Force in the Limit Equilibrium Slope Stability Analysis," Eng. Geol., vol. 240, hal. 140-148, 2018, doi: 10.1016/j.enggeo.2018.04.016.

[10] A. Santo, S. Del Prete, G. Di Crescenzo, dan M.
Rotella, "Karst Processes and Slope Instability: Some investigations in the Carbonate Apennine of Campania (Southern Italy)," Geol. Soc. Spec. Publ., vol. 279, hal. 59-72, 2007, doi: 10.1144/SP279.6.

[11] P. J. Sabatini, R. C. Bachus, P. W. Mayne, J. A. Schneider, dan T. E. Zettler, "Evaluation of Soil and Rock Properties," Geotech. Eng. Circ., vol. 5, hal. $385,2002$.

[12] H. Syaeful, W. Cakrabuana, dan Y. Rachael, "Investigasi Tanah di PTBGN-BATAN, Pasar Jumat, Jakarta, Indonesia," in Prosiding Seminar Geologi Nuklir dan Sumber Daya Tambang 2019, 2019, hal. 234-241.

[13] W. Norhaliza, B. Ismail, A. T. S. Azhar, dan N. J. Nurul, "Shear Strength of Remoulding Clay Samples Using Different Methods of Moulding Shear Strength of Remoulding Clay Samples Using Different Methods of Moulding," in IOP Conf. Series: Materials Science and Engineering 136 (2016), 2016, hal. 7, doi: 10.1088/1757899X/136/1/012018.

[14] X. Zhang, X. Liu, C. Chen, dan L. Kong, "Engineering Geology of Residual Soil Derived from Mudstone in Zimbabwe," Eng. Geol., 2020, doi: https://doi.org/10.1016/j.enggeo.2020.105785.

[15] Z. Hong, S. Liu, S. Shen, dan T. Negami, "Comparison in Undrained Shear Strength between Undisturbed and Remolded Ariake Clays," Geotech. geoenvironmental Eng., vol. 132, no. February, hal. 272-275, 2006, doi: 10.1061/(ASCE)1090-0241(2006)132:2(272).

[16] Supandi, Z. Zakaria, E. Sukiyah, dan A. Sudradjat, "The Correlation of Exposure Time and Claystone Propoerties at the Warukin Formation Indonesia," Geomate, vol. 15, no. 52, hal. 160-167, 2018, doi: https://doi.org/10.21660/2018.52.68175.

[17] A. Sridharan dan K. Prakash, "Classification Procedures for Expansive Soils," Proc. Inst. Civ. Eng. - Geotech. Eng., vol. 143, no. 4, hal. 235-240, 2009, doi: 10.1680/geng.2000.143.4.235.

[18] H. Syaeful dan W. Cakrabuana, "Analisis Potensi Ekspansi Batulempung Formasi Bojongmanik," $J$. Pengemb. Energi Nukl., vol. 21, no. 1, hal. 25-34, Agu 2019, doi: 10.17146/jpen.2019.21.1.5476.

[19] B. Oztekin, T. Topal, dan C. Kolat, "Assessment of Degradation and Stability of a Cut Slope in Limestone, Ankara-Turkey," Eng. Geol., vol. 84, hal. 12-30, 2006, doi: 10.1016/j.enggeo.2005.11. 012.

[20] Kementerian Pekerjaan Umum, "Peta Hazard Gempa Indonesia 2010," 2010.

[21] A. M. Youssef dan N. H. Maerz, "Slope Stability Hazard Assessment and Mitigation Methodology Along Eastern Desert Aswan-Cairo Highway, Egypt," J. King Abdulaziz Univ. Earth Sci., vol. 20, no. 2, hal. 161-181, 2009, doi: 10.4197/Ear.202.8 . 
[22] M. Grošić, S. Dugonjić, dan D. Udovič, "Designing, Constructing and Monitoring of Slopes in Rock Mass in Croatia," in Proceedings of the International Young Scholars' Symposium on Rock Mechanics - Boundaries of Rock Mechanics Recent Advances and Challenges for the 21st Century, 2008, hal. 463-469, doi: 10.1201/9780203883204.ch88. 
Analisis Geologi Teknik Longsor di Desa Kuatae, Kecamatan Kota Soe, Nusa Tenggara Timur Oleh: Heri Syaeful, dkk. 